\title{
Is electrosurgery fulguration a better procedure for Bartholin's gland cyst?
}

\author{
(D) Marcia Farina Kamilos ${ }^{1}$ \\ Celso Luiz Borrelli, \\ (iD) Ruben Sciuto ${ }^{4}$ \\ Fernanda Pereira Cotrim ${ }^{1}$ \\ Eduardo Carvalho de Arruda Veiga' \\ José Maria Soares Júnior ${ }^{1}$ \\ (iD) Maricy Tacla ${ }^{1}$ \\ Edmund Chada Baracat ${ }^{1}$
}

1. Disciplina de Ginecologia do Departamento de Obstetrícia e Ginecologia, Hospital das Clínicas, Faculdade de Medicina da Universidade de São Paulo, São Paulo, SP, Brasil 2. Departamento de Ginecologia do Hospital Heliópolis. São Paulo, SP, Brasil 3. Membro do Conselho Médico e do Conselho de Ginecologia Oncológica de Federação Brasileira de Ginecologia e Obstetrícia; São Paulo, SP, Brasil 4. General Medicine, School of Medicine of Uruguay. Statistical Advisor of the Uruguayan Society of Clinical Pathology, Montevideo, Uruguay

http://dx.doi.org/10.1590/1806-9282.66.2.201

\section{SUMMARY}

OBJECTIVE: To evaluate the effectiveness of electrosurgery fulguration as a treatment for Bartholin's gland cysts.

DESIGN: Retrospective study with a comparative control group performed on Hospital Brigadeiro and in the Disciplina de Ginecologia do Departamento de Obstetrícia e Ginecologia, Hospital das Clínicas, Faculdade de Medicina da Universidade de São Paulo from February 2005 to March 2009. Patients: Patients with Bartholin's gland cyst were divided into three treatment groups: group 1 electrosurgery ( $n=169$ cases); group 2 - gland excision with the conventional technique using a cold scalpel ( $n=51$ cases); group 3 - marsupialization ( $n=11$ cases). We reviewed the clinical and surgical history, physical examination, description of the surgical technique, postoperative results (success and complications), and follow-up data.

RESULTS: There is no difference between groups in relation to intraoperative bleeding, hematoma, and complete healing in a single treatment session. However, electrosurgery shows the lower percentage of recurrences $18(10,7 \%)$ compared to the Marsupialization technique (group 3, $p=.031)$. Recurrences occurred in $18(10,7 \%), 3(5,9 \%)$, and $4(36,4 \%)$ cases. After retreatment by the same technique, there was a complete cure rate of $90 \%$ (152/169) for group 1, and 98\% (50/51) for group 2. The cost of group 1 was lower than that of other groups.

CONCLUSION: The fulguration with electrosurgery of the capsule of Bartholin's cyst is an effective method of treatment, andthe cost of this technique is lower than the conventional technique and marsupialization.

KEYWORDS: Bartholin's glands. Cysts/diagnosis/therapy. Electrosurgery.

\section{INTRODUCTION}

The Bartholin's gland duct cyst (Bartholin cyst) is a relatively common condition, affecting about $2 \%$ of women during the reproductive ages ${ }^{1-3}$. The Bartholin's glands are two major vestibular glands, located deep in the perineum, between the bulb and the transverse muscle, with the function of making the vestibule lubrication for sexual intercourse, with drainage of secretions through ducts measuring about

DATE OF SUBMISSION: 23-Jul-2019

DATE OF ACCEPTANCE: 29-Jul-2019

CORRESPONDING AUTHOR: Eduardo Carvalho de Arruda Veiga

Departamento de Obstetrícia e Ginecologia, Faculdade de Medicina da Universidade de São Paulo; Sao Paulo, Brasil.

Av. Dr. Eneas de Carvalho Aguiar, 255 - Prédio do Instituto Central, 10 andar, sala 10167 - 05403-000. São Paulo - SP - Brasil

E-mail: eduveiga56@gmail.com 
$2 \mathrm{~cm}$ in length and which debouch at 4 and 8 hours in the vulvar vestibule, immediately lateral to the hymen ${ }^{4-6}$. The Bartholin cyst is a result of obstruction and cystic duct dilatation, resulting from some causes like local trauma, chronic inflammatory processes, even vaginal infections ${ }^{4-8}$.

The therapeutic approach is varied, and frequent recurrences have been reported with the use of some non-excisional methods ${ }^{2}$. The therapeutic option should consider the desire and possibility to preserve the function of the gland. Patients should be advised to understand, evaluate treatment alternatives, and communicate their preferences. The clinical profile and recurrence are important parameters in the therapeutic option?

After recurrence or persistence, the classic, definitive treatment can be performed by excision of the cystic capsule, a technique that requires hospitalization and deep anesthesia (spinal or general) with high costs. This procedure may have some complications, such as massive bleeding intraoperatively, dyspareunia, slow healing, hematomas, infections of the suture, and recurrence ${ }^{10,11}$. For this reason, alternatives have been considered by some investigators ${ }^{3,8}$.

Electrosurgery has proved applicable in various diseases of the lower genital tract as a method of excisional and destructive treatment. It has been used as first-line treatment of precursor lesions of cervical cancer, as well as in applications in the vagina and vulva, as a practical alternative, with low cost: outpatient, local anesthesia, low complication rates, and similar effectiveness ${ }^{12-15}$. Therefore, the aim of this study is to analyze the effectiveness of the treatment of the Bartholin cyst using a cystic capsule vaporization technique with a high-frequency electrosurgical unit compared to the classic excisional surgery and marsupialization.

\section{METHODS}

We performed a retrospective chart review of 169 women consecutively treated at the department of gynecology at the Hospital Brigadeiro for the treatment of Bartholin cyst. All procedures were performed in an outpatient clinic with local anesthesia, through drainage and cauterization capsuling using high-frequency electrosurgical unit (trademark Wavetronic 5000 - LLEP LOKTAL Master of Medical Electronics).

Patients had been treated in the period from February 2005 to March 2009. Inclusion criteria: patients with a diagnosis of Bartholin's gland cyst, unilateral or bilateral, where incision and drainage were performed, in addition to cauterization of the capsule, and who attended at least one follow-up for postoperative evaluation. Exclusion criteria: other types of cysts of the vulva and who did not attend any post-operative follow-up. We used the records of outpatient surgical procedures performed and analysis of medical records.

For the control group, we analyzed the medical records of 62 women who underwent Excision Conventional Cold Scalpel $(n=51)$ or Marsupialization $(n=11)$ for the treatment of Bartholin cyst, at the Disciplina de Ginecologia do Departamento de Obstetrícia e Ginecologia, Hospital das Clínicas, da Faculdade de Medicina da Universidade de São Paulo in the same period that the study group, and who attended at least one follow-up for postoperative evaluation. These procedures were performed in hospitalized patients, in the surgical center, with spinal anesthesia.

This study was approved by the Ethics Committee for Analysis of Research Projects of the Hospital das Clínicas on Jan 2010 (protocol $n^{\circ}$ 1306/09) and approved by the Research Ethics Committee of the University Hospital of USP on Dec 2011 (CEP-HU/USP: 1138/11), with the approval of the Informed Consent Form. Record-SISNEP CAAE (Nacional System of Research Ethics and Certified for Ethical Assessment): 1104.0.015.000-09.

\section{Electrosurgical technique}

The surgical technique usually consists in: infiltration anesthesia of the superficial mucosa of the vestibule with $2 \%$ lidocaine; linear incision of the mucosa and cystic capsule, 10 to $15 \mathrm{~mm}$ in length, using electrosurgical electrode needle, calibrated at the cutting function, power $45 \%$; draining of the cystic content and internal cleaning of the capsule with saline and gauze; complementation of local anesthesia around the capsule (as an option, pudendal nerve block procedure can be performed); vaporization of cystic capsule using spherical electrode 3 to $5 \mathrm{~mm}$ in diameter calibrated in the function of vaporization at $50 \%$ power; hemostasis review, preferably using gel hemostatic ferric perchlorate $50 \%$. In the presence of bilateral cysts, both sides were treated in the same session.

In cases without an inflammatory process prior to the procedure, one group received prophylactic antibiotics, and the other did not. Antibiotic therapy was given in cases of inflammation. In abscesses, generally, the procedure was performed at two steps: first 
session only incision, drainage, and administration of a broad-spectrum antibiotic; in the second session, after 7 to 10 days, completion of capsular vaporization.

Postoperative follow-ups were scheduled usually after $7,30,90$, and 180 days to ward off infections, evaluate healing, and possible relapse; annual controls were maintained to detect late relapses. Recurrence was defined as the occurrence of cyst or abscess in the region previously treated.

\section{Gland excision, conventional cold scalpel technique}

This procedure requires the excision of the Bartholin gland and surrounding tissue, with careful hemostasis and suturing. It should be performed only in the operating room to ensure appropriate anesthesia.

\section{Marsupialization technique}

This procedure consists of a vertical incision of the cystic mass in the vestibule and outside the hymenal ring. The incision should be about 1.5 to $3 \mathrm{~cm}$ and followed by suturing of the inner edge of the incision to the external mucosa.

\section{STATISTICAL ANALYSIS}

We analyzed the frequency of complete healing, intraoperative and postoperative complications, recurrence, and compared these data with the alternative surgical technique for the control group. The results were described using absolute frequencies and percentages for qualitative variables, average, standard deviation, and confidence intervals of $95 \%$ for quantitative variables (previously Kolmogoroy-Smimov test to adjust normal distribution). For the comparison groups, we employed the Chi-square or Fisher test, Yates continuity correction test, and Student's tests on qualitative and quantitative variables, respectively. We used a significance level of 0.05 , and the software used was SPSS version 19.0.

\section{RESULTS}

\section{Group 1}

Fulguration of the cystic capsule with Electrosurgery: of the 169 patients who underwent Electrosurgery, 88 (52\%) had involvement of the cyst on the right, $73(43 \%)$ left, $8(5 \%)$ the disease was bilateral. The mean age of patients was $36 \pm 9,4$ years (17-60 years). In relation to parity, 20 (14\%) were nulliparous or had only one abortion, 36 (25\%) had at least one cesarean birth and without vaginal delivery, and $88(61 \%)$ at least one vaginal delivery. The mean diameter of the cysts was $3.1 \pm 1.5 \mathrm{~cm}$.

Intraoperative complications occurred in $3(2 \%)$ cases, with severe bleeding that was controlled with hemostatic sutures, without hospitalization nor blood transfusion. The mean postoperative follow-up was $15 \pm 14,7$ months. The time for complete healing was about 20-40 days.

Regarding the final result of the surgery, represented by complete healing, 87\% (147/169) of patients had satisfactory healing, considered complete cure without late complications; 10,7\% (18/169) had recurrence; and $2 \%(4 / 169)$ showed significant scarring complications (one case of endometriosis with vulvar pain, dyspareunia and associated vaginismus, which was reoperated and persists with pain; 1 case of persistent local pain, and reoperation performed excision of fibrous capsule, asymptomatic after surgery; 2 cases of scar retraction, but without significant symptoms, and without the need for surgical correction). After retreatment by the same technique, the cure rate was $90 \%(152 / 169)$.

The mean interval to recurrence was 9.3 months (2-40 months). Recurrence occurred in less than 6 months ( 2 and 5 months) in 3 cases $(16.8 \%)$, over 6 months in 15 cases (83\%; 5 cases occurred over 1 year).

Among the 18 cases of recurrence, $15(83 \%)$ had a diagnosis of cyst and 3 (17\%) of abscess, 15 (83\%) had a history of Bartholin's gland pathology, 12 cases had previous drainage, 10 (56\%) did not use and 4 (22\%) used prophylactic antibiotics, in $4(22 \%)$ the antibiotic regimen was therapeutic, with slightly higher index of postoperative infection $(5 / 18,28 \%)$. There was no statistical difference in the mean age and cyst diameter.

After recurrence, 4 patients underwent classical excision, and 8 underwent the same technique, 4 patients did not undergo a new procedure, and 2 were not reported. Of the 8 patients who underwent the same technique, 5 remained asymptomatic after an average of 6 months, 1 relapsed again and underwent classical excision, 2 patients did not return for control.

\section{Group 2: Gland excision conventional cold scalpel}

In the group that underwent excision of the cystic capsule with cold scapel ( $n=51), 20 / 47$ (43\%) had involvement of the gland on the right, 26 (55\%) left, 1 (2\%) case bilateral. 
TABLE 1. ELECTROSURGERY FULGURATION OF THE CYST OF BARTHOLIN'S GLAND: A COMPARATIVE STUDY WITH CONVENTIONAL COLD KNIFE GLAND EXCISION AND MARSUPIALIZATION

\begin{tabular}{|c|c|c|c|c|c|c|c|}
\hline $\begin{array}{l}\text { Procedure study } \\
\text { size }\end{array}$ & Age (years) & $\begin{array}{l}\text { Affected side } \\
\text { n (\%) side }\end{array}$ & $\begin{array}{l}\text { Duration of Bar- } \\
\text { tholin pathology } \\
\text { (month) }\end{array}$ & $\begin{array}{l}\text { Previously treated } \\
\text { or with recurrence } \\
\text { for Bartholin pa- } \\
\text { thology } \mathrm{n} / \mathrm{N}(\%)\end{array}$ & $\begin{array}{l}\text { No. Cysts/No. } \\
\text { Abscesses (\%) }\end{array}$ & $\begin{array}{l}\text { Diameter } \\
(\mathrm{cm})\end{array}$ & $\begin{array}{l}\text { Anes- } \\
\text { thesia } \\
\text { type/n }\end{array}$ \\
\hline $\begin{array}{l}\text { Electrosurgery } \\
N=169\end{array}$ & $\begin{array}{l}35.9 \pm 9.4(17 \\
-60)\end{array}$ & $\begin{array}{l}\text { 88(52.1\%)R; } \\
\text { 73(43.2\%)L; } \\
\text { 8(4.7\%)Bil. }\end{array}$ & $35.8 \pm 45.4(1-252)$ & $67 / 101(66.3 \%)$ & $163 / 6(96.4 \%)$ & $\begin{array}{l}3.1 \pm 1.5 \\
(1-10)\end{array}$ & local 169 \\
\hline $\begin{array}{l}\text { conventional cold } \\
\text { knife gland excision } \\
\mathrm{N}=51\end{array}$ & $\begin{array}{l}35.8 \pm 9.9(18 \\
-61)\end{array}$ & $\begin{array}{l}\text { 20/47(42.6\%)R; } \\
\text { 26/47(55.3\%)L; } \\
\text { 1/47(2.1\%)Bil. }\end{array}$ & $21.6 \pm 20.3(1-84)$ & $35 / 48(72.9 \%)$ & $47 / 4(92.2 \%)$ & $\begin{array}{l}3.2 \pm 1.4 \\
(2-10)\end{array}$ & spinal 51 \\
\hline Marsupialization & $30 \pm 9.3$ & $4(36.4 \%) \mathrm{R}$ & $31.8 \pm 31.8$ & $10 / 11$ & $8 / 3$ & $3.6 \pm 2.1$ & \\
\hline$N=11$ & $(19-46)$ & $\begin{array}{l}\text { 6(54.5\%)L; } \\
\text { 1(9.1\%)Bil. }\end{array}$ & $(1-108)$ & $(90.9 \%)$ & $(72.7 \%)$ & $(1,5-8)$ & spinal 11 \\
\hline $\begin{array}{l}\text { p-value and Cl95\% } \\
\text { Electrosurgery vs. } \\
\text { conventional cold } \\
\text { knife gland excision }\end{array}$ & $\begin{array}{l}.948 \zeta \\
{[-2.90 ; 3.10]}\end{array}$ & $.294 \phi$ & $\begin{array}{l}.002 \zeta \\
{[5.32 ; 23.08]}\end{array}$ & $\begin{array}{l}.408 \phi \\
{[-.22 ; 0.09]}\end{array}$ & $\begin{array}{l}.365 \Psi \\
{[-.04 ; .12]}\end{array}$ & $\begin{array}{l}.672 \xi \\
{[-.57 ; .37]}\end{array}$ & \\
\hline $\begin{array}{l}\text { p-value and C195\% } \\
\text { Electrosurgery vs } \\
\text { Marsupialization }\end{array}$ & $\begin{array}{l}.046 \zeta \\
{[.13 ; 11.67]}\end{array}$ & $\begin{array}{l}.551 \phi \\
-\end{array}$ & $\begin{array}{l}.774 \zeta \\
{[-23.30 ; 31.50]}\end{array}$ & $\begin{array}{l}.184 \Psi \\
{[-.44 ; .04]}\end{array}$ & $\begin{array}{l}.012 \Psi \\
{[.01 ; .50]}\end{array}$ & $\begin{array}{l}.298 \zeta \\
{[-1.45 ; .45]}\end{array}$ & \\
\hline
\end{tabular}

Age, Duration of Bartholin pathology and Diameter are presented as mean \pm standard deviation (minimum and maximum) $\phi$ Chi Square test $\zeta$ Student test $\Psi$ Yates's correction for continuity

TABLE 2. ELECTROSURGERY FULGURATION OF THE CYST OF BARTHOLIN'S GLAND: A COMPARATIVE STUDY WITH GLAND EXCISION CONVENTIONAL COLD KNIFE AND MARSUPIALIZATION

\begin{tabular}{|c|c|c|c|c|c|c|c|}
\hline $\begin{array}{l}\text { Procedure, } \\
\text { study size }\end{array}$ & $\begin{array}{l}\text { Intraoperative } \\
\text { complication } \\
\text { (bleeding) } \mathrm{n} / \mathrm{N} \\
(\%)\end{array}$ & $\begin{array}{l}\text { Immediate post- } \\
\text { operative compli- } \\
\text { cation (hemato- } \\
\text { ma) n/N (\%) }\end{array}$ & $\begin{array}{l}\text { Follow-up } \\
\text { after surgery } \\
\text { (months) }\end{array}$ & $\begin{array}{l}\text { Postopera- } \\
\text { tive infection } \\
\mathrm{n} / \mathrm{N}(\%)\end{array}$ & $\begin{array}{l}\text { Recur- } \\
\text { rences } \\
n / N(\%)\end{array}$ & $\begin{array}{l}\text { Time at recur- } \\
\text { rence }\end{array}$ & $\begin{array}{l}\text { Other compli- } \\
\text { cations } \mathrm{n} / \mathrm{N} \\
(\%)\end{array}$ \\
\hline $\begin{array}{l}\text { Electrosurgery } \\
N=169\end{array}$ & $3 / 169(1,8 \%)$ & 0/169 (0\%) & $\begin{array}{l}14.9 \pm 14.7(1 \\
-54)\end{array}$ & $8 / 52(15,4 \%)$ & $\begin{array}{l}18 / 169 \\
(10,7 \%)\end{array}$ & $\begin{array}{l}3 / 18(16.7 \%) \\
<6 \mathrm{~m} ; \\
15 / 18(83.3 \%) \\
>6 \mathrm{~m}\end{array}$ & $4 / 169(2,4 \%)^{\star *}$ \\
\hline $\begin{array}{l}\text { gland excision } \\
\text { conventional } \\
\text { cold knife } \\
\mathrm{N}=51\end{array}$ & $1 / 51(2 \%)$ & $3 / 51(5,9 \%)$ & $\begin{array}{l}20.4 \pm 24.7 \\
(1-84)\end{array}$ & $11 / 51(21.6 \%)$ & $\begin{array}{l}3 / 51 \\
(5,9 \%)\end{array}$ & $\begin{array}{l}2 / 3(66.7 \%)< \\
6 \mathrm{~m} ; 1 / 3 \\
(33.3 \%)>6 \mathrm{~m}\end{array}$ & $2 / 51(3.9 \%)^{\star \star \star}$ \\
\hline $\begin{array}{l}\text { Marsupializa- } \\
\text { tion } \quad \mathrm{N}=11\end{array}$ & $0 / 11(0 \%)$ & $0 / 11(0 \%)$ & $\begin{array}{l}24.2 \pm 26.3(1 \\
-84)\end{array}$ & $1 / 11(9.1 \%)$ & $\begin{array}{l}4 / 11 \\
(36.4 \%)\end{array}$ & $\begin{array}{l}1 / 4(25 \%)<6 m \\
3 / 4(75 \%)>6 m\end{array}$ & $0 / 11(0 \%)$ \\
\hline $\begin{array}{l}\text { p-value and } \\
\text { Cl95\% Elec- } \\
\text { trosurgery vs. } \\
\text { gland excision } \\
\text { conventional } \\
\text { cold knife }\end{array}$ & $1.000 \eta \dot{\eta}-$ & $\begin{array}{l}.012 \eta ́ \\
{[-.12 ; .00]}\end{array}$ & $\begin{array}{l}.136 \zeta \\
{[-12.79 ; 1.78]}\end{array}$ & $\begin{array}{l}.419 \varphi \\
{[-.21 ; .09]}\end{array}$ & $\begin{array}{l}.457 \varphi \\
{[-.03 ; .13]}\end{array}$ & $\begin{array}{l}.128 \eta \dot{\eta} \\
{[-.99 ; .06]}\end{array}$ & $\begin{array}{l}.915 \Psi \\
{[-.07 ; .04]}\end{array}$ \\
\hline $\begin{array}{l}\text { p-value and } \\
\text { C195\% Electro- } \\
\text { surgery vs Mar- } \\
\text { supialization }\end{array}$ & $1.000 \eta \dot{~}$ & $1.000 \eta ́$ & $\begin{array}{l}.273 \zeta \\
{[-27.15 ; 8.55]}\end{array}$ & $\begin{array}{l}.946 \Psi \\
{[-.13 ; .25]}\end{array}$ & $\begin{array}{l}.041 \Psi \\
{[-.55 ;-.09]}\end{array}$ & $1.000 \eta ́$ & $1.000 \eta ́$ \\
\hline
\end{tabular}

Follow-up after surgery is presented as mean \pm standard deviation (minimum and maximum). ${ }^{*}$ Patients only with prophylactic antibiotics. * ${ }^{*}$ Local endometriosis with severe pain (1), local pain (1), scar retraction extensive (2). ${ }^{\star \star \star}$ Local pain (2). $\varphi$ Chi-Square test $\eta$ Fisher Test $\zeta$ Student test $\Psi$ Yates's correction for continuity

The mean age was 36 years-old ( \pm 10 years-old). In relation to parity, 21 (41\%) of the women had a history of at least one vaginal delivery, but no description of possible episiotomy or perineal lacerations, 13 (26\%) only had cesareans, 9 (18\%) were nulliparous or had only had an abortion, and in $8(15 \%)$ there was no description.

The mean time between the onset of symptoms and treatment was 22 months (1-84 months) in 41 women. There was a history of recurrence or 
previous treatment for Bartholin's gland pathology in 35 women ( $73 \%$ of 48 reported cases), and a median of $3(1-10)$ previous surgical drainage in 19 cases. The initial diagnosis was a cyst in 47 (92\%) cases, and abscess in $4(8 \%)$. The mean diameter of the cysts was $3.2 \mathrm{~cm}$ $(2-10 \mathrm{~cm})$ reported on 37 patients. Regarding intraoperative complications, $1(2 \%)$ case of severe bleeding was reported. Complications in the immediate postoperative hematoma occurred in $3(6 \%)$ cases, treated with local ice.

Patients were instructed to return for evaluation of healing in 7-14 days, and 30-60 days. After this period, they were discharged and returned to routine gynecological appointments between 6 months and annually. The mean follow-up was $20.4 \pm 24.7$ months (1-84 months). Infection and/or dehiscence occurred in 11 (22\%) cases; non-disabling local pain for 4 months in $2(4 \%)$ cases. The time of complete healing was about 20-30 days. Complete healing was reported in 48 (94\%) cases, and recurrence in $3(6 \%)$ ( 2 cases occurred after 4 months of surgery, a new excision was performed, a new relapse occurred, marsupialization was performed, and the patient remains asymptomatic), and in 1 case relapse occurred after 2 years (drainage was performed, the deep cyst remains asymptomatic). There was a mean of 11 months (4-24 months) for recurrence. Considering the cases of retreatment by the same technique, the complete cure rate was $98 \%$ (50/51 cases). In cases of recurrence, the mean age was 35 years, the mean cyst diameter $2.8 \mathrm{~cm}$, all had a history of previous treatment.

\section{Group 3: Marsupialization}

In patients who underwent Marsupialization $(n=11)$, the mean age was $30 \pm 9,3$ years-old. Six women (55\%) had at least one vaginal delivery without episiotomy description, $2(18 \%)$ had exclusively cesarean, $3(27 \%)$ were nulliparous.

The mean time between the onset of symptoms and Marsupialization was 31,8 months (1-108 months). Ten patients (91\%) had a history of Bartholin's disease, or prior treatment with an average of six episodes of recurrences (3-15) in 9 cases, and previous average drainage 3 (1-7). A cyst was diagnosed in 8 (73\%) cases, and abscess in $3(27 \%)$. Mean diameter cyst: $3.6 \pm 2.1$ $\mathrm{cm}(1.5-8 \mathrm{~cm})$ in 8 cases.

There were no intraoperative and immediate postoperative complications. The average follow-up time after treatment was $24 \pm 24,2$ months (1-84 months). Only $1(9 \%)$ postoperative infection with dehiscence of the surgical scar was described in a case previously uninfected. The average time of healing was about 15-30 days. Complete healing occurred in 7 (67\%) cases, relapses in 4 (33\%) cases, after 18 months on average (1 at 5 months, and 3 after 1-2 years). Two patients underwent the excisional method, and two remain with asymptomatic cysts. In cases of recurrence, the mean age was 28 years-old, the mean cyst diameter was $2.8 \mathrm{~cm}$, and all had a history of previous treatment.

\section{Comparison between groups}

Figures 1, 2, and 3 summarize the comparative data between groups. There is a significant difference regarding age between groups 1 and $3(p=0.046)$, with younger patients in the Marsupialization group; groups 1 and 2 are homogeneous concerning this variable. The affected side was homogeneous in all groups $(p>0.05)$. The mean duration of the disease was different from the statistical point of view between groups 1 and 2 , and it was greater in the first group $(\mathrm{p}=0.002)$. The percentage of recurrences or pretreatment of Bartholin gland pathology was similar in all groups ( $p>.05)$, which translates homogeneity in the groups regarding this variable. We found a larger number of cysts in patients treated with Electrosurgery (96.4\%) in comparison to those who were treated by the technique of Marsupialization (72.7\%), $p=.012$. The size of the cysts was similar among the study groups, with no significant differences. The final results of Table 2 indicate that intraoperative complications were similar between the groups $(p>0.05)$. The immediate postoperative complications were lower in group 1 than in group 2 (significant hematoma in the immediate postoperative period occurred only in group 2 , in $3(6 \%)$ cases $(p=0.012)$, with no differences between groups 1 and 3, 0\% in each group). All the patients had the same value for the average follow-up after surgery, with no statistical differences $(15,18$, and 24 months for groups 1,2 , and 3 , ( $p>0.05)$. The percentage of postoperative infections was distributed equally between the study groups $(p>0.05)$. Complete healing in a single treatment session, no significant late complications, was obtained in 147 (87\%) patients in group 1, 48 (94.1\%) cases in group 2, and 7 (63.6\%) patients in group $3(p$ $=0.159, p=0.091$, respectively). The Electrosurgery technique presented the lowest percentage of recurrences compared to the Marsupialization technique $(\mathrm{p}=$.041). The recurrence time, in terms of mean and standard deviation, was similar between the groups. 
FIGURE 1. A - AGE (YEARS) - ${ }^{*} P=0.046$ - COMPARISON BETWEEN GE AND GM; B - DURATION OF BARTHOLIN PATHOLOGY (MONTHS) - *P=0.002 COMPARISON BETWEEN GE AND GG; C - PREVIOUSLYTREATED OR WITH RECURRENCE FOR BARTHOLIN PATHOLOGY (\%); D - NUMBER OF CYSTS/NUMBER ABSCESSES $(\%)-{ }^{*} \mathrm{P}=0.012$ COMPARISON BETWEEN GE AND GM
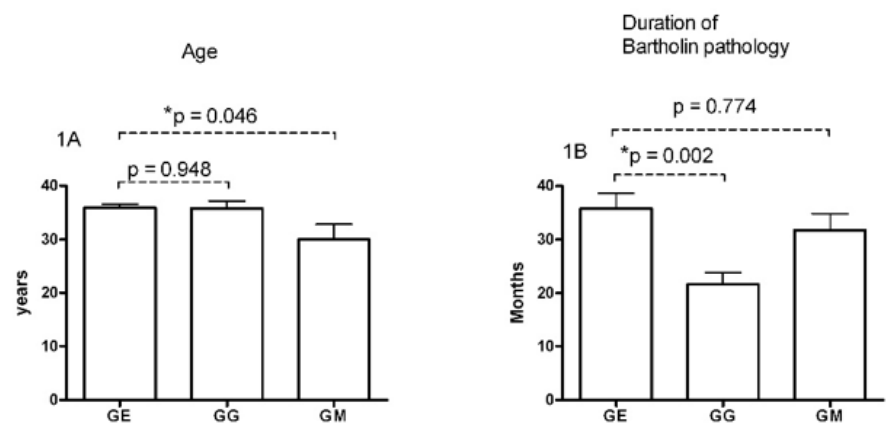

Previously treated for recurrence of Bartholin

Number of cysts/number of abscesses pathology
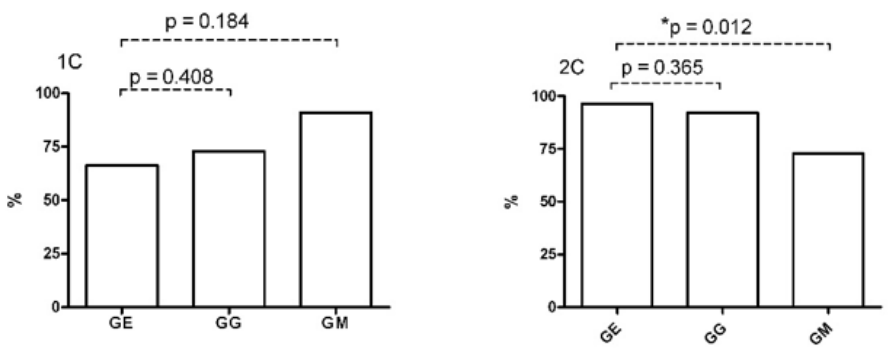

GE - Electrosurgery; GG - Conventional cold knife Gland excision; GM - Marsupialization. Chi-Square test; Yate's correction for continuity.

FIGURE 2. A - AFFECTED SIDE BILATERAL OF SURGERY (\%); B - AFFECTED SIDE RIGHT OF SURGERY (\%); C AFFECTED SIDE LEFT OF SURGERY (\%); D - MAXIMUM DIAMETER OF SURGERY (CM);
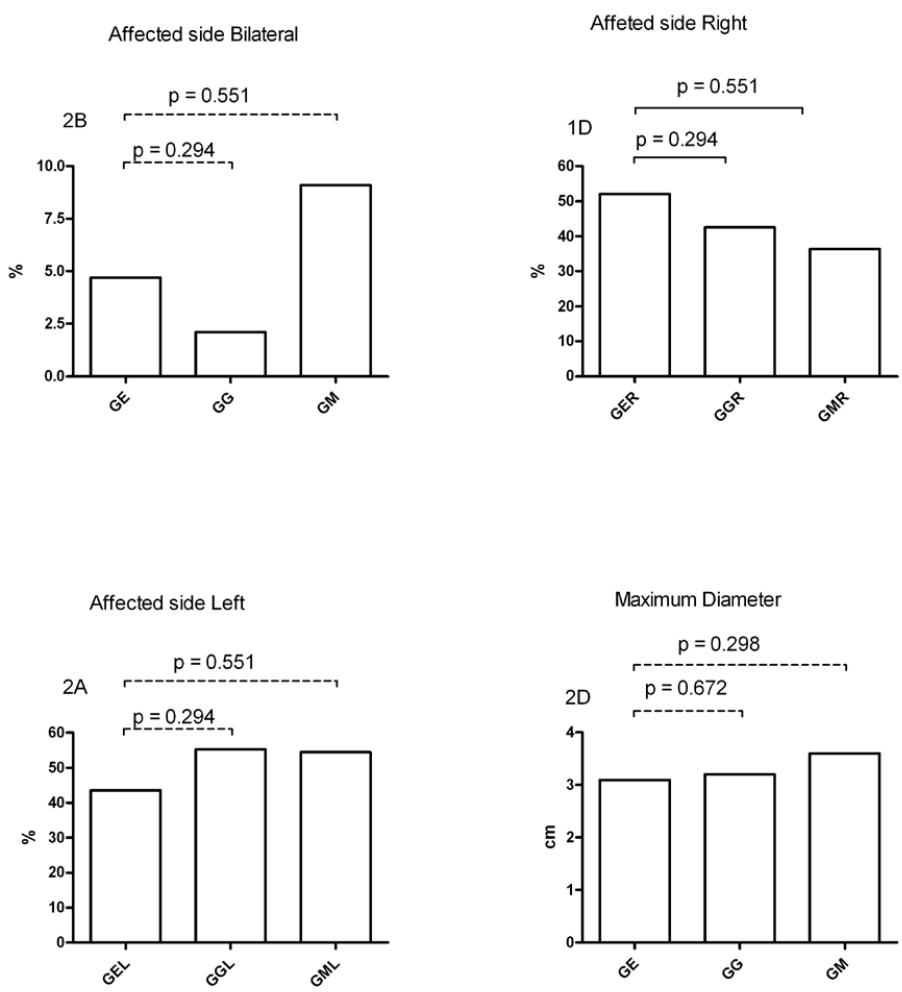

GE - Electrosurgery; GG - Gland excision conventional cold knife; GM - Marsupialization; GER - Electrosurgery - GGR - gland excision conventional cold knife - GMR - Marsupialization; GEL - Electrosurgery; GGL-Gland excision conventional cold knife; GML - Marsupialization - Chi-Square test: Yatés correction for continuity. 


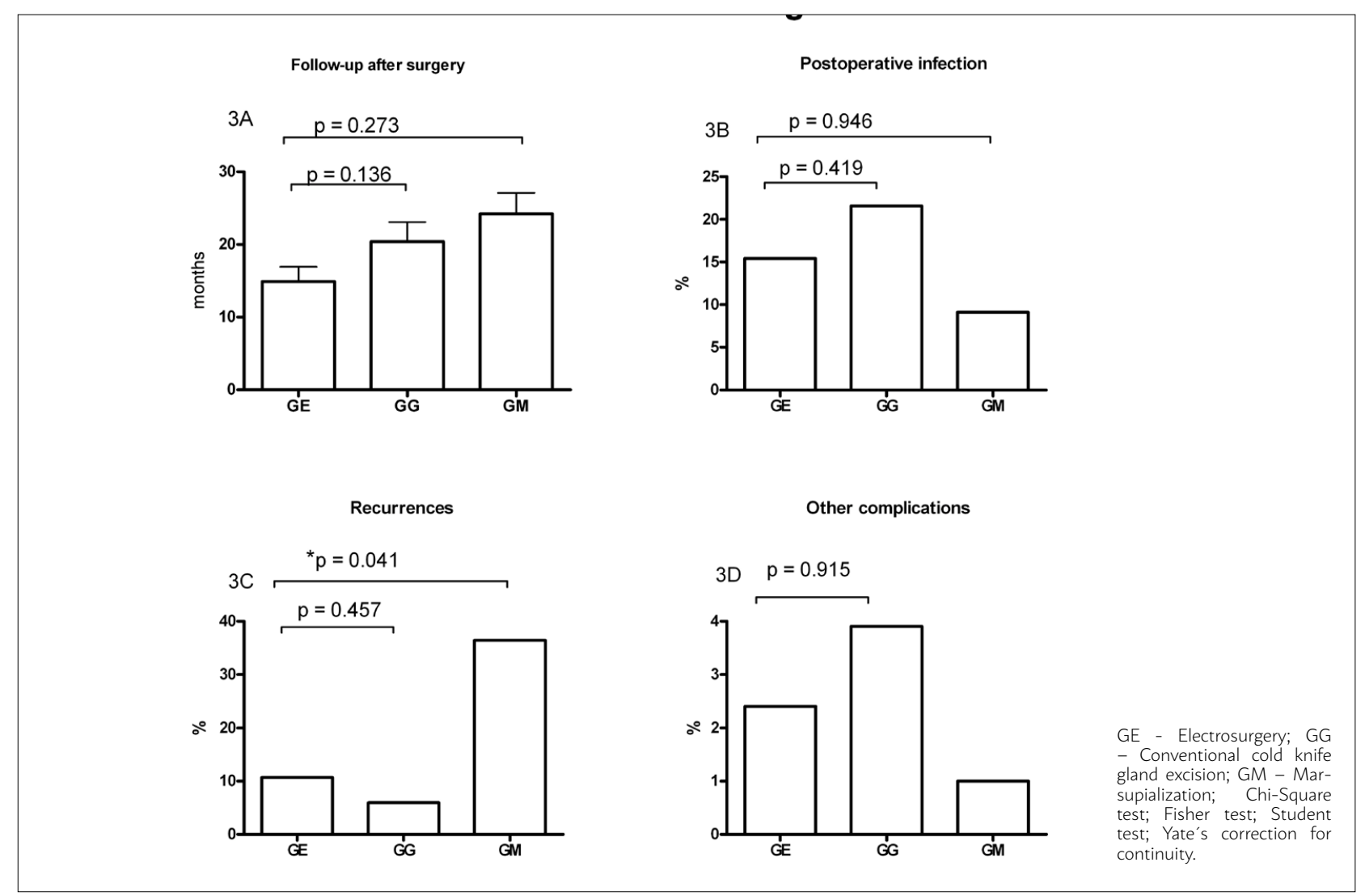

Finally, we studied other postoperative complications, finding no statistically significant differences between the different techniques.

\section{DISCUSSION}

The cysts of Bartholin's gland are common disorders, with important clinical implications because of the pain, dyspareunia, infection, and its recurrent character ${ }^{16}$. The long period between the onset of symptoms and access to definitive treatment stands out in these groups. Our data showed that the fulguration of the cystic capsule with electrosurgery might be effective for the treatment of cysts of Baratholin.

Our study showed that the Electrosurgical technique is innovative when considering its high efficiency associated with easy workability and cost, both compared to the conventional excisional, considered the gold standard in recurrent or persistent cases; it also presents less risk of intraoperative bleeding. This is particularly important considering the high demand for public services ${ }^{17}$. Marsupialization showed a higher percentage of recurrences compared to Electrosurgical technique and conventional excision. However, our study had some limitations concerning the surgical procedures, since they were performed by different medical staffs, and retrospective analysis ${ }^{18}$.

Relapses in excisional and destructive techniques can be explained by the presence of other compartments, great extension of the capsule, deep location, fibrosis, difficult surgical access, probably as a consequence of repeated recurrences and infectious processes. The follow up of these patients should be long because of late recurrences, even over 3 years $^{1-6}$.

Comparative studies will be needed to assess the best initial approach technique in uninfected cysts and abscesses in order to decrease the time of disease progression and recurrence. The groups have the same baseline, which shows they were homogeneous at the beginning of the study. The Electrosurgery technique demonstrated that it was safe regarding the rate of intraoperative complications and immediate postoperative, infection, and other complications, it was also effective due to the low percentage of recurrence, in agreement with the contents of the scientific literature. The fulguration with Electrosurgery of the 
capsule of the Bartholin cyst represents an effective method of treatment, with a better cost/benefit ratio when compared to conventional cold scapel gland excision and greater cure rate compared to Marsupialization. Recurrence can occur late in all methods, and a long follow-up period is advisable.

We conclude that, despite the limitations of this study, the electrosurgical technique can be recommended for the treatment of cysts of the Bartholin gland, as a great alternative to high-demand services.

\section{Funding}

This study was supported by Fapesp, CNPq, and Capes (Brasíla-Br) Statement: The authors do not have any conflict of interest

\section{Acknowledgments:}

This study was supported by grants from Capes, Fapesp, and CNPq.

\section{Competing interests}

The authors declare they have no competing interests

\section{Authors' contributions}

MFK - made substantial contributions to the concept, study design, and definition of intellectual content; was involved in literature search, data analysis, statistical analysis, and manuscript preparation, in drafting the article or revising it critically for important intellectual content, and gave final approval to the version to be published.
CLB - was involved in data analysis and statistical analysis; in drafting the article or revising it critically for important intellectual content; and gave final approval to the version to be published.

RS - was involved in data analysis and statistical analysis; in drafting the article or revising it critically for important intellectual content; and gave final approval to the version to be published.

FPC - was involved in data analysis and statistical analysis; in drafting the article or revising it critically for important intellectual content; and gave final approval to the version to be published.

ECVA - was involved in data analysis and statistical analysis; in drafting the article or revising it critically for important intellectual content; and gave final approval to the version to be published.

JMSJ - made substantial contributions to the concept, study design, and definition of intellectual content; was deeply involved in drafting the article or revising it critically for important intellectual content; and gave final approval to the version to be published.

MT - made substantial contributions to the concept, study design, and definition of intellectual content; was involved in literature search, data analysis, statistical analysis, and manuscript preparation; in drafting the article or revising it critically for important intellectual content; and gave final approval to the version to be published.

The authors have no commercial, proprietary, or financial interest in the products or companies described in this article.

\section{RESUMO}

OBJETIVO: Avaliar a eficácia da fulguração da eletrocirurgia como tratamento para os cistos da glândula de Bartholin.

MÉTODOS: Estudo retrospectivo, grupo controle comparativo realizado no Hospital Brigadeiro e disciplina de Ginecologia do Departamento de Obstetrícia e Ginecologia do Hospital das Clínicas da Faculdade de Medicina da Universidade de São Paulo, de fevereiro de 2005 a março de 2009. Pacientes com cisto de glândula de Bartholin foram divididos em três grupos de tratamento: grupo 1 - eletrocirurgia ( $n=169$ casos); grupo 2 - excisão da glândula com técnica convencional utilizando bisturi frio ( $n=51$ casos); grupo 3 - marsupialização ( $n=11$ casos). Revisamos a história clínica e cirúrgica, o exame físico, a descrição da técnica cirúrgica, os resultados pós-operatórios (sucesso e complicações) e os dados de acompanhamento.

RESULTADOS: Não há diferença entre os grupos em relação ao sangramento intraoperatório, hematoma e cicatrização completa em uma única sessão de tratamento. No entanto, a eletrocirurgia mostrou o percentual mínimo de recidivas, 18 (10,7\%), em relação à técnica de marsupialização (grupo 3, p = 0,031). Recorrências ocorreram em 18 (10,7\%), três (5,9\%) e quatro (36,4\%) casos. Após o retratamento pela mesma técnica, houve taxa de cura completa: 90\% (152/169) para o grupo 1 e 98\% (50/51) para o grupo 2 . O custo do grupo 1 foi menor do que os dos outros grupos.

CONCLUSÃo: A fulguração com eletrocirurgia da cápsula do cisto de Bartholin é um método efetivo de tratamento, mas o custo dessa técnica é menor do que a técnica de convenção e a marsupialização.

PALAVRAS-CHAVE: Glândulas vestibulares maiores. Cistos/diagnóstico/terapia. Eletrocirurgia. 


\section{REFERENCES}

1. Kaufman RH, Faro S, Brown D. Benign diseases of the vulva and vagina. $5^{\text {th }}$ ed Philadelphia: Elsevier Mosby; 2005. p.240-9.

2. Quinn A. Bartholin gland diseases clinical presentation. Manual of Medscape. [cited 2013 Jan 13]. Available from: http://emedicine.medscape.com/ article/777112

3. Wechter ME, Wu JM, Marzano D, Haefner H. Management of Bartholin duct cysts and abscesses: a systematic review. Obstet Gynecol Surv. 2009;64(6):395-404.

4. Peters WA $3^{\text {rd }}$. Bartholinitis after vulvovaginal surgery. Am J Obstet Gynecol. 1998;178(6):1143-4.

5. Patil S, Sultan AH, Thakar R. Bartholin's cysts and abscesses. | Obstet Gynaecol. 2007;27(3):241-5.

6. Baracat EC. Patologia do trato genital inferior. São Paulo: Roca;2005. p.45-55.

7. Bhide A, Nama V, Patel S, Kalu E. Microbiology of cysts/abscesses of Bartholin's gland: review of empirical antibiotic therapy against microbial culture. J Obstet Gynaecol. 2010;30(7):701-3.

8. Pundir J, Auld BJ. A review of the management of diseases of the Bartholin's gland. | Obstet Gynaecol. 2008;28(2):161-5.

9. Ozdegirmenci O, Kayikcioglu F, Haberaql A. Prospective randomized study of marsupialization versus silver nitrate application in the management of Bartholin gland cyst and abscesses. J Minim Invasive Gynecol. 2009;16(2):149-52

10. Hill DA, Lense J.. Office management of Bartholin gland cysts and abscesses Am Fam Physician. 1998;57(7):1611-6, 1619-20.
11. Fambrini M, Penna C, Pieralli A, Fallani MG, Andersson KL, Lozza V, et al Carbon-dioxide laser vaporization of the Bartholin gland cyst: a retrospective analysis on 200 cases. J Minim Invasive Gynecol. 2008,15(3):327-31.

12. BRASIL. Ministério da Saúde, Instituto Nacional de Câncer. Diretrizes brasileiras para o rastreamento do câncer do colo do útero. Rio de Janeiro: Ministério da Saúde/ Instituto Nacional de Câncer; 2011. p.65-81.

13. Lacey C), Woodhall SC, Wikstrom A, Ross |. 2012 European guideline for the management of anogenital warts. J Eur Acad Dermatol Venereol. 2013;27(3):e263-70

14. Heller DS, van Seters M, Marchitelli C, Moyal-Barracco M, Preti M, van Beurden M. Update on intraepithelial neoplasia of the vulva: proceedings of a Workshop at the 2009 World Congress of the International Society for the Study of Vulvovaginal Diseases, Edinburgh, Scotland, September 2009. J Low Genit Tract Dis. 2010;14(4):363-73.

15. Vlastos AT, Levy LB, Malpica A, Follen M. Loop electrosurgical excision procedure in vulvar intraepithelial neoplasia treatment. | Lower Genital Tract Dis. 2002;6(4):232-8.

16. Figueiredo ACN, Duarte PEFSAR, Gomes TPM, Borrego IMP, Marques CAC. Bartholin's gland cyst: management with carbon-dioxide laser vaporization. Rev Bras Ginecol Obstet. 2012;34(12):550-4

17. Sabzi F, Niazi M, Ahmadi A. Rare case-series of electrocautery burn following off-pump coronary artery bypass surgery. I Inj Violence Res. 2014;6(1):44-9.

18. Telles DC, Castro WH, Gomes RS, Souto GR, Mesquita RA. Morphometric evaluation of keratocystic odontogenic tumor before and later marsupialization. Braz Oral Res. 2013;27(6):496-502. 